\title{
Student Dropout from Foundation Program at Modern College of Business \& Science, Sultanate of Oman
}

\author{
Dr. Venkat Ram Raj Thumiki ${ }^{1}$ \\ ${ }^{1}$ Assistant Professor \& Coordinator-Marketing Program, Department of Business \& Economics, Modern College of \\ Business and Science, Muscat, Sultanate of Oman. \\ Correspondence: Dr. Venkat Ram Raj Thumiki, Assistant Professor \& Coordinator-Marketing Program, Department \\ of Business \& Economics, Modern College of Business and Science, Muscat, Sultanate of Oman. E-mail: \\ venkat@mcbs.edu.om
}

Received: July 9, 2019

Accepted: August 19, 2019

Online Published: August 21, 2019

doi:10.5430/ijhe.v8n5p118

URL: https://doi.org/10.5430/ijhe.v8n5p118

\begin{abstract}
Main reasons for student dropout from higher education may be low academic performance, poor socialization skills, low confidence levels, busy social life and financial issues. As students' dropout from higher education has been rising, there is a need to understand this problem for finding suitable solutions. Research objectives for this institutional research are to explore patterns in dropout data at Foundation program, establish criteria for identifying students at-risk of dropout and identify areas of improvement for reducing dropout rate, as the dropout problem is high at Foundation level of the college. Research methodology includes application of exploratory study based on analysis of secondary data pertaining to 22 semesters, Spring 2012 to Summer-I 2017. Findings revealed that 1966 students dropped out from Foundation program during the study period with an average of 94 students per semester. Dropout rate was higher among males and was more at Levels I and IV. Though dropout happened in Foundation, academic departments would also experience major loss, as Foundation is the 'feeder program' for other bachelor's programs. It is recommended to have a dropout process flow-chart not only to understand the exit journey of dropping students, but also to reverse the journey. It is recommended to set up a dropout committee, design an early warning system for creating alerts and bifurcate Foundation department into Language sub-department and Technical sub-department (Math and IT courses). It is further recommended to have an effective data management system that would enable administration to reduce dropout rates and create a 'feel good' environment for the students.
\end{abstract}

Keywords: dropout, stopout, system dropout, retention

\section{Introduction}

An effective higher educational ecosystem of a nation aims at transforming the society into knowledgeable society (UNESCO, 1991). In their endeavor to impart knowledge and enrich the learners with useful information, the higher educational institutions (henceforth referred to as HEIs) not only need to design high utility programs and courses (Duke, 2005), but they also aim at increasing student enrolment and student retention (Braxton \& McClendon, 2002) through emphasizing both academic and non-academic issues (ibid). While academic issues include, improvement of programs and learning facilities, non-academic issues entail, general facilities which are equally significant for the success of HEI (Organisation for Economic Co-operation and Development, 2007). A HEI can achieve growth in terms of number of academic activities performed, number of programs offered, global collaborations, advances in research, consultancy and training activities and most importantly, number of student registration (Going Global, British Council Analysis, 2012). While college administration focuses on increasing student strength, they tend to ignore the students that are discontinuing their education before completion of the stipulated program or number of years of study (Cervini, 2015). Hence, addressing student retention has become an indispensable action (Lillis, 2011). One of the serious problems that management of any HEI face is following the right mechanism appropriately deal with the discontinuation of the students from their respective programs.

According to Cambridge dictionary (2017), college dropout is a tendency among students to leave higher education system before completion or in an unusual way. Student dropout refers to discontinuation of education by a learner before completion of stipulated number of courses or hours (Swail, 2004). Dropout occurs when students disengage themselves from college education and terminate themselves from the higher education system (Alexander, Entwisle 
\& Kabbani, 2001). Student dropouts are of different types; 'stopout' - students who leave and re-join the institution after some time, 'institutional dropout' - students who leave one institution and join another institution, and 'system dropout' - students who discontinue their education (Chen \& DesJardins, 2010). According to Herzog (2005), institutional dropout a.k.a. 'transfer-out' (changing the institution) may not affect the national statistics related to higher education. Dropout studies essentially include identifying at-risk students who are considered to have a high probability of dropping (Harton, 2015).

\section{Literature Review}

Retaining students until they complete their designated qualifications has societal significance (Lee \& Burkam, 2003). One important aspect to note is that those who continue (persisting students) had better experiences with their school life than those who drop (Ridge, Farah \& Sami, 2013). Moreover, student-related factors that influence dropout include, poor academic performance, bad behavior, lack of self-esteem, to name a few. (Johnson, 1997). As dropout risk is a serious concern for educators and students (McGaha \& Fitzpatrick, 2005), there is a need to identify the factors that contribute to student dropout (Johnson, 1997). Low GPA or failure (MacDonald, 1992; Kern, Fagley \& Miller, 1998; Cambiano, Denny \& DeVore, 2000), poor socialization skills (Oswald \& Clark, 2003), low confidence about their ability to complete tasks (Vazquez-Abad, Winer \& Derome, 1997) and busy social life, such as marriage, (Bradburn, 2002) could be some of the factors that influence student dropout from college. College dropout rates have been increasing as most of the students drop before completing their educational programs (Selingo, 2016). This problem is not only occuring in developing nations, but it is also apparent in developed countries such as the UK and Ireland as student dropout has been increasing (Baker, 2017; O'Donovan, 2017). Additionally, in the USA alone 3.9 million students dropped out of college in 2015-2016 (Barshay, 2017). Dropouts in the Middle East have been alarming as well. According to El Shammaa (2010), the dropout rate is around 25\% in the Emirates.

The government of Oman has been supporting higher education through scholarships, aimed at providing quality manpower to the industry (Rassekh, 2004; Al-Hamadi, Budhwar \& Shipton, 2007). There has been a significant increase in the number of higher educational institutions as well as student intake in higher education in Oman over the past two decades (Al-Shmeli, 2011; Al-Sarmi, 2014). However, this mission has encountered an unforeseen problem (Kay, 2015), i.e., an increasing number of students dropping from higher education. With more than 10,000 students dropped out from college in 2014-2015 (Times of Oman, 26 Sep, 2016), figures indicate that an average of 7,000 students leave higher education every year in Oman (Shaibany, 2016). According to the official statistics, college dropout is a serious problem that has been creating hindrance in achieving the higher education mission of the Government in Oman (Muscat Daily, 28 Dec, 2016). The statistics indicates the seriousness of the problem and requests special attention by all stakeholders of higher education in Oman (Pourmohammadi, 2016).

\subsection{Need for the Study}

Student dropout has been a major problem in many educational institutions (Swail, 2004) as it is evident that student retention rates have been decreasing in 2-year programs (Astin, Korn \& Green, 1987) and 4-year programs (Bradburn, 2002). Leaky bucket theory could be applicable in this case (Ehrenberg, 1988) as student dropout could lose revenue. This could be a major concern for two key stakeholders of higher education in any country, industry and society at large (Reyhner, 1992). Thus, there arises a need to investigate main reasons underlying student dropout from their respective programs. As student dropout can be categorized as a 'crisis' in education industry, it needs crisis management strategies to be applied while dealing with this problem (Dianda, 2008). At the Modern College of Business \& Science (henceforth referred to as MCBS), the General Foundation Program (henceforth referred to as GFP) is the largest program with students' numbers ranging from 600 to 800 per semester. Hence, dropout from this program will have a significant impact on the institution. Until now, no study is being conducted to understand this phenomenon at the college, and no concrete suggestions have been given to address this critical issue. Though, the college administration has been addressing this issue in various meetings and committees, there is no systematic study conducted. Hence, there arises a need for the study.

\subsection{Objectives of the Study}

This institutional research on student dropout at the Foundation level is aimed at achieving the following objectives:

- To explore patterns and trends in student dropout from the foundation;

- $\quad$ To establish criteria for understanding the students at risk of dropout from foundation; 
- To make recommendations for student retention at the foundation program.

\subsection{Scope and Limitations of the Study}

Scope of the current study was limited to the Foundation program only offered by the Department of General Foundation Program (GFP). Data pertaining to 22 semesters only from Spring 2012 to Summer-I 2017 has been analyzed. The current research report is based on analysis of secondary data only. Applications of research results is limited to the Foundation program and cannot be generalized or extended to other forms of education in the college such as Bachelor's or Master's programs.

\section{Research Methodology}

This section explains the research methodology adopted for this paper and it comprises of description of secondary data used. Secondary data makes a significant contribution to understanding the problem and identifying solutions (Saunders, Lewis \& Thornhill, 2007). Total number of students registered in Foundation program during the study period is 15597, out of whom 1966 students dropped out. Secondary data pertaining to dropped-out students was collected from the Database Department of the college. Various data points that were considered for analysis include, semester dropped, bachelor's program of the dropped-out students, level left, gender, whether part-time or full-time, details of sponsors, courses studied by dropped out students along with grades in those courses. Data privacy (Bogdanov et al., 2014) needs to be followed while analyzing institutional data. Information that was not collected as part of data privacy policy of MCBS was, name of the student, ID and date of birth (MCBS Policy Manual, 2016). Along with internal database, relevant statistics and information were collected from various valid sources such as websites of HEI's, published reports in newspapers, books related to higher education and research papers on student dropout.

\subsection{Data Analysis Tools and Techniques}

The data related to student dropout from Spring 2012 to Summer-I 2017 and collected from the Database Department was analyzed using Pivot Tables in MS Excel (Saunders et al., 2007).

\subsection{About General Foundation Program (GFP) at Modern College of Business and Science (MCBS)}

As per MCBS Student Handbook 2017-18 (pp. 11), the Foundation program at MCBS prepares students for bachelor's education in accordance with the guidelines of Oman Academic Accreditation Authority - (OAAA). The three main subject areas in the Foundation program are English, Mathematics and Information Technology. The program comprises of four levels from 'beginners to advanced - Levels I to IV'. Different courses presented in Appendix 5 are explained below:

1. ENGL 0011, 0021, 0031 \& 0041 - Speaking, Listening and Note-taking: The objectives are: to develop fluency and correctness in speaking English; to increase conversational vocabulary; to understand, practice, and adapt features of pronunciation by listening to recorded material; to increase conversational listening skills and to organize and present short lectures.

2. ENGL 0012, 0022, 0032 \& 0042 - Reading: The objectives are: To develop writing skills including essay development, organization, vocabulary, and editing for grammar, punctuation and structure; to develop reading skills and strategies.

3. ENGL 0013, 0023, 0033 \& 0043 - Grammar and Writing: The objectives are: to review grammar rules, to understand the meaning and use of these structures; to recognize and use these structures correctly in speaking and writing.

4. MATH 20, $21 \&$ COSC 10 - Mathematics and Computer Science: The objectives are: to develop the computational and analytical skills.

\subsection{Analysis of Student Dropout Data}

The dropout of 1966 out of 15597 students indicates 12.6 percentage dropout from the Foundation program. Data presented in Table 1, clearly indicates high dropout rate with an average of 89 students per semester during the study period. Most importantly, during this period, 34 students paid the registration fee but did not join the program. Though this finding is not within the scope of current study, it creates the need for further study to find out whether there exists a relationship between this behavior and dropout behavior (future scope of current study). 
Table 1. No. of students dropped during Spring 2012 to Summer-I 2017

\begin{tabular}{cc}
\hline No. dropped & Average dropout per semester \\
\hline & \\
1966 & 89 \\
\hline
\end{tabular}

\section{Which gender left}

Usually, female students are more at MCBS. Around $72 \%$ are females. But the dropout is not proportionate. Table 2 clearly indicates that dropping behavior is more among male students than the female students. There is a need to find out the reason for dropout among male students (future scope of current study).

Table 2. Gender distribution of students who dropped from Foundation program

\section{Which national left}

\begin{tabular}{ccc}
\hline Gender & Number & Percentage \\
\hline Female & 1027 & 52.2 \\
Male & 939 & 47.8 \\
Grand Total & $\mathbf{1 9 6 6}$ & $\mathbf{1 0 0}$ \\
\hline
\end{tabular}

According to the internal database, nearly 97\% of the student body at MCBS comprises of Omani nationals and 3\% other nationalities. The dropout pattern is proportionate to this number. Dropout behavior is same for both Omani's and non-Omanis. However, it is required to retain the students irrespective of their nationality status.

Table 3. Nationality distribution of students who dropped from Foundation program

\section{Which semester left}

\begin{tabular}{ccc}
\hline Nationality & Number & Percentage \\
\hline Omani & 1929 & 98.0 \\
Non-Omani & 37 & 2.0 \\
Grand Total & $\mathbf{1 9 6 6}$ & $\mathbf{1 0 0}$ \\
\hline
\end{tabular}

Though the dropout pattern is evenly distributed, it can be positively interpreted that the trend has been decreasing. Highest dropouts can be noticed during Spring-2014, Fall-2013, Spring-2013 and Fall-2012 semesters.

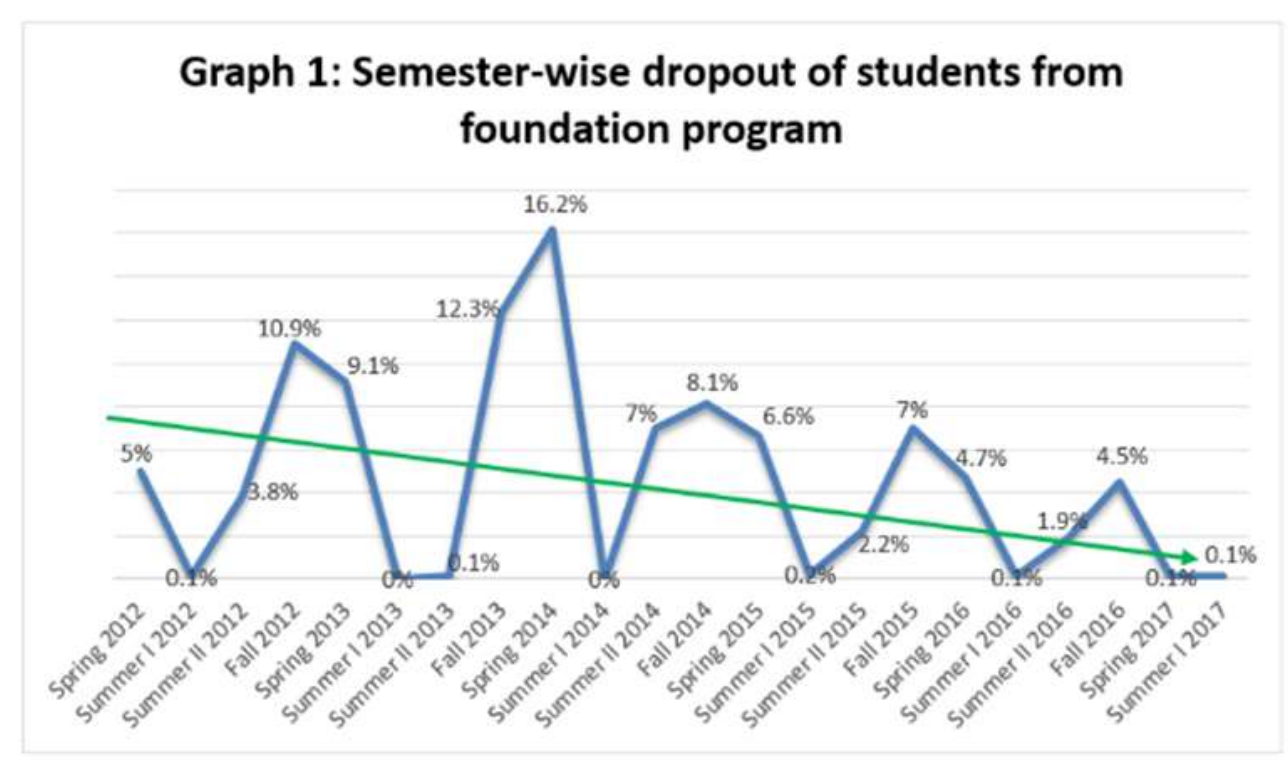

\section{Which level left}

Out of 1,966 students who dropped out of Foundation program during Spring 2012 to Summer-I, 2017, highest number, i.e., 41\% (806 students) dropped after Level I and next highest, $29 \%$ dropped from Level 4. Thus, it is clear that the dropout is more at the entrance and at the exit levels. This data is close to the reality wherein several 
studies confirmed that the dropouts are more after first year (MacDonald, 1992; Woodley, Thompson \& Cowan, 1992; Benn, 1995; Tickle, 2015) due to which Level I can be referred to as 'make or break' level (Kift, 2014).

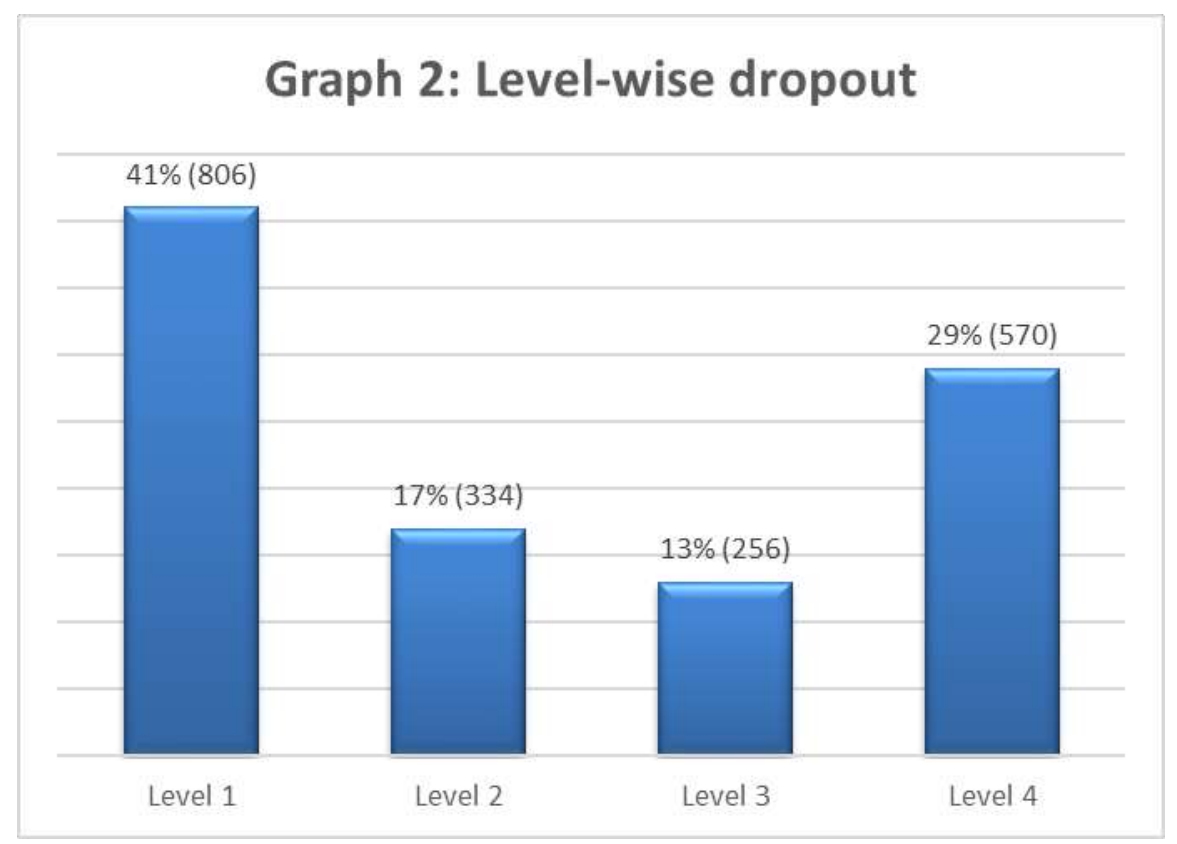

\section{Full time / Part time}

According to the registration data, usually around $86 \%$ of registered students in any semester are full-time and only $14 \%$ are part-time. But the dropout ratio is not proportionate to the registration data. Dropout is noticed more among part-time students. Nearly $22 \%$ of those who dropped out are part-time students.

Table 4. Full time and Part time status of dropped out students

\begin{tabular}{ccc}
\hline Status & Number & Percentage \\
\hline Full time & 1545 & $78.6 \%$ \\
Part time & 421 & $21.4 \%$ \\
Grand Total & $\mathbf{1 9 6 6}$ & $\mathbf{1 0 0 \%}$ \\
\hline
\end{tabular}

\section{Potential program of dropped out students (could have joined which program)}

Though some students join Foundation program only for the GFP certificate, majority of them join as a part of requirement to continue their higher education. Students proceed to either Associate or Bachelor's programs based on their interest. Hence, Foundation program is called as a 'feeder program', meaning, students from Foundation join the main-stream Associate or Bachelor's programs. That is the reason why dropout at the Foundation program affects registration into credit courses and main stream Associate and Bachelors' programs at MCBS. Table 5 clearly indicates the loss to various Associate and Bachelor's programs due to student dropout at Foundation program. Though biggest loss was to Bachelor of Science Business Administration, Associate of Science Business Administration and Bachelor of Science Airport Management, other programs too lost a number of student registrations due to dropout from Foundation. 
Table 5. Potential program of dropped out students

\begin{tabular}{cc}
\hline Program & Noundation \\
\hline Bachelor of Science in Business Administration & 663 \\
Associate of Science in Business Administration & 268 \\
Bachelor of Science in Airport Management & 235 \\
Bachelor of Science in Aviation Management & 159 \\
Associate of Science in Information Communication Technology & 134 \\
Bachelor of Science in Information Systems & 117 \\
Bachelor of Arts in Economics & 82 \\
Bachelor of Science in Health and Safety Management & 61 \\
Bachelor of Science in Computer Science & 55 \\
Bachelor of Science in Statistics & 51 \\
Bachelor of Science in Accounting & 49 \\
Bachelor of Science in Commercial Law & 30 \\
Non-Academic English & 22 \\
Bachelor of Science in Information Security & 12 \\
Associate of Science in Computer Science & 10 \\
Bachelor of Science in Transportation and Logistics Management & 6 \\
Not clear & 6 \\
Associate of Arts in Business Administration & 4 \\
Undecided & 1 \\
Grand Total & 1 \\
\hline
\end{tabular}

\section{Sponsors of dropped students}

Student sponsors are one of the key stakeholders of a higher educational institution (Mainardes, Alves \& Raposo, 2010). Students who dropped from Foundation program during the study period were funded by 66 sponsors comprising of different organizations. There are also self-sponsored students along with parent-sponsored and MCBS sponsored students. There is a need to know whether the management of MCBS is aware of these 23 dropout cases.

Table 6. Sponsors of dropped out students

\begin{tabular}{ccc}
\hline Sponsor & Number & Percentage \\
\hline Different sponsors & 1291 & $66 \%$ \\
Funded by parent(s) & 247 & $13 \%$ \\
Self-funded & 405 & $20 \%$ \\
Funded by MCBS & 23 & $1 \%$ \\
Grand Total & $\mathbf{1 9 6 6}$ & $\mathbf{1 0 0 \%}$ \\
\hline
\end{tabular}




\section{Courses studied, and grades achieved by dropped out students}

Table 7. Courses studied \& grades achieved by dropped out students arranged in descending order

\begin{tabular}{ccccccc}
\hline Course & $\boldsymbol{N o}$. & $\boldsymbol{D}$ & $\boldsymbol{A W}$ & $\boldsymbol{W}$ & $\boldsymbol{Z}$ & $\boldsymbol{F}$ \\
\hline ENGL 0013 & 1923 & 209 & 40 & 26 & 55 & 751 \\
ENGL 0012 & 1835 & 224 & 40 & 27 & 48 & 626 \\
ENGL 0011 & 1774 & 218 & 35 & 21 & 48 & 523 \\
ENGL 0021 & 1057 & 137 & 18 & 16 & 26 & 221 \\
ENGL 0022 & 1001 & 147 & 11 & 11 & 31 & 174 \\
ENGL 0023 & 937 & 114 & 14 & 7 & 26 & 157 \\
ENGL 0033 & 932 & 118 & 16 & 13 & 21 & 200 \\
ENGL 0032 & 872 & 114 & 14 & 14 & 13 & 129 \\
ENGL 0031 & 850 & 98 & 14 & 10 & 18 & 120 \\
ENGL 0042 & 697 & 104 & 13 & 10 & 23 & 117 \\
ENGL 0041 & 651 & 76 & 11 & 7 & 17 & 105 \\
ENGL 0043 & 634 & 68 & 14 & 6 & 17 & 90 \\
MATH 10 & 530 & 1 & 16 & 16 & 17 & 119 \\
COSC 10 & 244 & 3 & 3 & 7 & 8 & 49 \\
MATH 20 & 186 & 2 & 3 & 3 & 8 & 41 \\
ORNT 001 & 124 & - & 1 & - & 10 & 22 \\
MATH 21 & 1 & - & 40 & 26 & 55 & 751 \\
Grand Total & $\mathbf{1 4 2 4 8}$ & & & & & \\
\hline
\end{tabular}

Failure and low academic performance could be a reason for dropout (Cambiano et al., 2000). It would be helpful to analyse the results of courses studied by dropped students (Smith \& Naylor, 2001; Doll, Eslami \& Walters, 2013; Rausch \& Rausch, 2015). Table 7 presents grades achieved by the dropped students in different Foundation courses. Though, they studied some credit courses, from other programs, the current analysis is limited to Foundation courses only. It can be seen that ENGL 0013 is studied more number of times with highest ' $\mathrm{F}$ ' grade (failure) and ' $Z$ ' grade (registered but never attended the class). Data presented in Table 7 and Graph 2 are synchronizing, with more failures in Level-1 courses and more dropout in Level-1 respectively. Courses in the other three Levels are studied less number times as there are less takers for these courses due to higher dropout rate in Level - I. There is a need to further analyze this data and look deeper to understand the patterns in student dropout from Foundation. D is the passing grade, AW indicates administrative withdrawal (such as lack of attendance), and W refers to student's self-withdrawal due to personal reasons (Source: Registration Department, MCBS).

\section{Recommendations}

This section provides valuable suggestions and workable solutions for avoiding recurrence of the problem or at least reducing the degree of recurrence of the problem, i.e., student dropout from Foundation program at MCBS. Main goal is to reverse the trend and discourage or delay the exit process (within the legal and ethical framework). 


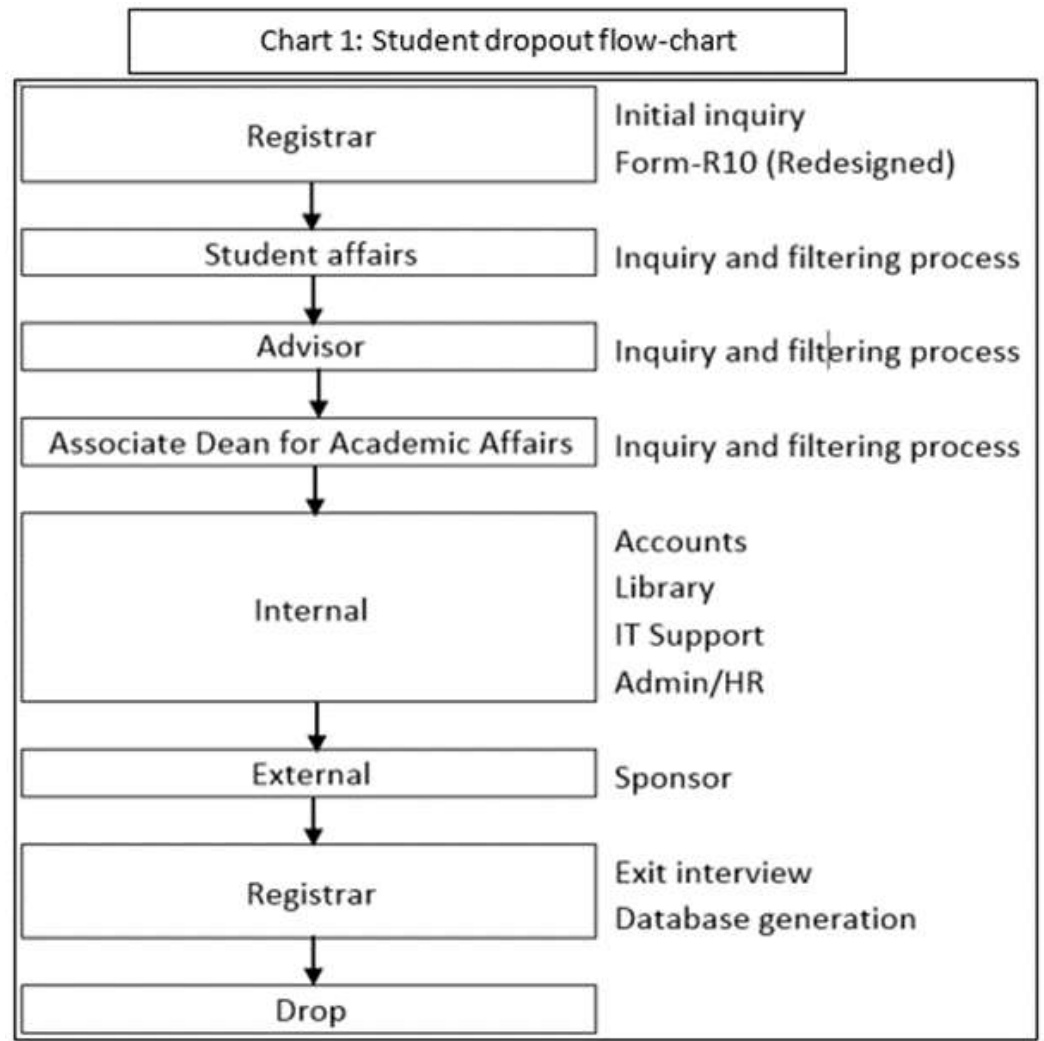

\section{$>$ Create dropout process flow-chart}

Designed by the author

As of now there is no flow chart explaining the process of a student's exit at the time of dropout.

Existing system: According to the Registration department, a student's dropout (exit) journey starts with filling a 'Clearance From' named as, 'FORM-R10' (Appendix 1). The student then visits five departments, Library, Accounts, Student Affairs, IT Support and Administration, seeking clearance signatures on the form. Though the researcher was told that the student needs to approach, his/her Advisor for signature, there was no provision for Advisor's signature on 'Form-R10'. The student returns the filled-in and signed Form-10 to the Registration department and quits the college after financial formalities.

New \& improved system with a 'DROPOUT PROCESS FLOW-CHART': There is a need to have a flow-chart in place so that key points can be identified, and filters can be inserted. The aim of this suggestion is not to apply 'hard management' technique but to make the exit process more systematic through which both the parties (student and institution) can benefit. The main purpose of 'filters' in the exit flow is to have a detailed dialogue with the dropping students, understand main reasons for dropout, and persuade the students to continue their studies instead of dropping. In fact, the 'filters' (officers) need to be trained in this aspect. Student Affairs should be removed from the list of functional departments signing on clearance form and should be made the first filter in the newly recommended dropout process flow-chart. Advisors could be made the second filter and Associate Dean of Academic Affairs could be the third filter. The student will then proceed to taking clearance signatures from four functional departments, including Accounts, Library, IT support and Admin/HR. Then students will go back to Registrar's department for providing needed data (database generation) which can be collected separately or as part of their exit interview. Including the sponsor can be agreed upon after discussion.

Redesign the Clearance Form, 'FORM-R10': There is a need to redesign the 'Clearance Form', FORM-R10. Below are some valuable suggestions:

- As Office of the Registrar is the concerned department, it should not be mentioned as one of the departments.

- Make it error-free. It is mentioned as 'Registration Office' on the main form and as 'Registrar's Office' on the counterfoil form. 
- Digitalize the process. The approvals can be made online by the concerned officers. This will also enable data collection and compilation easy.

- Instead of a counter-foil, the photocopy or scanning can be used so that duplication of signatures can be avoided.

- Further there is a need to know whether it is a 'stopout' or 'institutional dropout' or 'system dropout'. Though the data mentions that two students were transferred to another college, it is questionable that throughout 22 semesters, out of total of 1966 students, only two students were transferred.

\section{$>\quad$ Collect / generate dropout data}

As data is the lifeline of business decisions (Drucker, 1967; The Economist, 2013), it is essential to generate data related to student dropout. If the outgoing student cannot be stopped, at least get as much information as possible from the outgoing student. For this purpose,

- Design the existing forms and make separate forms for graduating students and dropping out students. Form-10 for graduating students and Form-11 for dropping out students. Main purpose is to collect specific and separate information from different categories outgoing students.

- FORM-R11 needs to contain the filters mentioned in the above suggestion along with collecting more data. A separate exercise needs to be conducted for this purpose.

- Data collection and exit interview can be either separated as two different functions or the exit interview form can contain different sections aiming at collecting all relevant data from dropping students.

\section{$>\quad$ Suggestions related to database on student dropout}

Though the Database department has been effectively managing institutional data, there is further need for improvement in some of following areas:

- Have clear numbers and statistics about student dropout.

- Data analytics need to be applied.

- Error free data collection and data entry are required.

- All contact details need to be collected.

- All required details need to be collected at the time of dropout.

- Feedback interview to be made mandatory and the questionnaire / feedback need form to be filled by the dropping out students. Though there is an exit interview in place, there is a need to further systematize the process through the 'Registration and Dropout Committee'.

\section{$>\quad$ Form the 'Registration and Dropout Committee'}

Though this research was on student dropout, the analysis discovered another category, firstly, those who registered in Foundation program but did not join and secondly those who registered for a course but did not attend a single class. Hence there is a need for Registration and Dropout Committee to monitor both situations. The Committee will be Headed by the Registrar with Associated Dean for Academic Affairs, Student Affairs officer and Deputy Heads of various academic departments as members. The committee can be formed within the existing Administration framework of MCBS.

\section{$>\quad$ Open an exclusive center to deal with issues related to dropout}

John Hopkins University, USA operates an exclusive center dedicated to the dropout crisis (Appendix 4). Named as 'Everyone Graduates Center', it conducts studies not only at the University level but much wider research up to the national level. It is recommended to open such as center at MCBS. Scope of the center can be decided based on the experience.

\section{$>\quad$ Provide advising and mentoring for Foundation students}

There is a need to have Advising and Mentoring activity in the Foundation program. This facilitates close monitoring of the students. Advisors can act as 'filters' in the exit journey of dropping out students presented in Chart 1.

\section{$>\quad$ Design an early warning system for identifying potential dropouts}

The best way of reducing student dropout is to identify the potential dropouts and implementing an early warning system (Balfanz \& Fox, 2011; Hoff, Olson \& Peterson, 2015). Below are some of the suggestions to identify the 
students 'at-risk' of dropping out based on secondary data analysis and discussions with experts (focus groups). For this purpose, 'at-risk' student can be identified at two points, firstly at the time of entry and secondly while studying. While identifying potentially at-risk students at the time of entry or admission falls under the future scope of current research, this section presents how to identify students 'at-risk' of potential dropout while they are studying.

- $\quad$ Student has been failing a course several times

- Student has been failing various courses several times

- $\quad$ Student attended classes but did not do any assessment

- Student has withdrawn from the course

- $\quad$ Student did not attend final exam

- $\quad$ Student received AW

- $\quad$ Student received Z

- $\quad$ Student received warning letters - whether administrative or behavioural

$>$ Involve top management: Top-down approach

Top management of MCBS will be aware of and will be able to understand the intensity of the problem if it is involved. It is recommended that Associate Dean level officer needs to be involved in the process of student dropout. The same is presented in Chart 1 (student dropout flow-chart).

\section{$>$ Adopt inclusive approach}

It is recommended that more offices and more officers be involved in the process of student dropout. As recommended in the flow-chart, various 'internal' parties such as, Registration and Dropout Committee, Deputy Heads of all academic departments, advisors, top officers (Associate Deans) and Student Affairs Officers need to be involved in the process of student dropout. In addition to internal parties, 'external' parties such as sponsors and parents too could be involved within the legal framework.

\section{$>\quad$ Course restructuring at Foundation level}

Based on the analysis of dropout data, following suggestions can be made related to academic management:

- Separate attention needs to be paid in case of Level-1. For example, changing classroom management activities at Level-1, increasing number of contact hours for Level-1 courses, changing the evaluation patterns at Level-1, etc. As the researcher is not competent to suggest evaluation methodology for English Language courses, it is recommended for the management of GFP to take it further based on research and expertise. Regarding changing evaluation patterns, the idea is not to dilute the evaluation process but to work on it. Though, the GFP department has been extensively working on the same, it is recommended that the objective needs to be defined as, 'reduce dropouts'. Once, the problem is viewed and understood from this dimension, the whole methodology of working will change.

$\circ \quad$ Another suggestion is pertaining to MATH and IT courses offered at the Foundation program. Some of the research questions (suggestions) could be, 'can these two courses be separated from the Foundation program?' If this suggestion is agreed upon, the new framework contains two sub-departments under the Foundation department: English Foundation and Technical Foundation. All Language courses will be offered in English Foundation (there will be huge demand for this from corporate sector) and MATH and IT courses will be offered in Technical Foundation.

\section{English + MATH \& COSC $=$ GFP}

\section{$>\quad$ Prolong the exit process (within the legal and ethical framework)}

The main aim of this suggestion it to make a student continues his or her education instead of discontinuing his/her studies. As part of student retention strategy, MCBS can make the exit process more elaborated and detailed. Elaborated exit process enables the managers understand main reason(s) for dropout which could help them either stop the dropping out students or reduce future dropouts. Below are some of the related suggestions: Though some of the suggestions appear to be argumentative, the researcher has included them to initiate a discussion about this key 
issue in the institution. (Disclaimer: Some of these suggestions are mostly aimed at initiating a debate and discussion about student dropout at MCBS)

- Involve more parties inside and outside the college (inclusive approach presented in the previous point). Involvement by more parties prolongs the process.

- Create a no-exit rule: Students cannot drop in the middle of the academic year.

- Create a no-exit semester in an academic year: Student cannot drop after Fall (for example), must study Spring and can drop after Spring only. Legal framework needs to be studied for implementing such strategies.

\section{Conclusion}

Dropout is not an uncommon phenomenon. There could be various reasons for student dropout from higher education. Different techniques such as RCA-Route Cause Analysis (Rooney \& Heuvel, 2004) and WWW-What Went Wrong / What Will Work analysis (Edmondson \& Cannon, 2005) are available to investigate the problem and find better solutions. Current research was conducted to explore some of the reasons for student dropout from the Foundation program at MCBS. This institutional research provides insights into the problem. The main objectives of this research are to reverse the trend of dropout, retain more students, and increase persistence. There is a need to create enthusiasm amongst depressed students and enhance student engagement. This will enable spread of positive word-of-mouth and create a 'feel good' environment for the students of Modern College of Business and Science.

\section{Future Scope of the Study}

Studies can be conducted to identify students 'at-risk' of dropout at the time of admission itself. There is a need to further conduct studies to understand the reasons for students registering but not joining MCBS. The current study can also be extended to find out the reasons for higher dropout rates among male students.

\section{Funding}

This study was funded by the Modern College of Business and Science, under the institutional research category.

\section{References}

Al-Hamadi, A.B., Budhwar, P.S. \& Shipton, H. (2007). Management of human resources in Oman. The International Journal of Human Resource Management, 18(1), 100-113. https://doi.org/10.1080/09585190601068383

Alexander, Karl L, Entwisle, Doris. R. \& Kabbani, Nader (2001). The dropout process in life course perspective: Early risk factors at home and school. Teachers College Record, 103(5), 760-822. http://dx.doi.org/10.1111/0161-4681.00134

Al-Sarmi, Abdullah bin Mohammed (2014). From one university to 54 higher education institutions: The experience of Oman in higher education, Showcase Middle East, Qs-Showcase-AMEA, Feb, 11. Retrieved from http://qsshowcase.com/main/from-one-university-to-54-higher-education-institutions-the-experience-of-oman -in-higher-education/

Al-Shmeli, Saif. (2011). Tertiary education in Oman: Catching up rapidly, Chapter 8 in, Tertiary education in small states Planning in the context of globalization, edited by Michaela Martin \& Mark Bray, IIEP Paris, France, 181-192.

https://unesdoc.unesco.org/in/rest/annotationSVC/DownloadWatermarkedAttachment/attach_import_15acee1 7-98ea-49cb-acfb-23bf452ce3d7?_=212196eng.pdf

Astin, A., Korn, W. \& Green, K. (1987). Retaining and satisfying students. Educational Record, 68(1), 36-42. https://eric.ed.gov/?id=EJ352791

Baker, Simon. (2017). Dropout rate for young UK students rises again. World University Rankings, The Times Higher education, $\quad 9^{\text {th }} \quad$ March. https://www.timeshighereducation.com/news/dropout-rate-young-uk-students-rises-again\#survey-answer

Balfanz, Robert. \& Fox, Joanna. (2011). Early warning systems: Foundational research and lessons from the field. Everyone Graduates Center, Johns Hopkins University, Philadelphia, USA. https://docplayer.net/15154851-Early-warning-systems-foundational-research-and-lessons-from-the-field.htm 1

Barshay, Jill. (2017). Federal data shows 3.9 million students dropped out of college with debt in 2015 and 2016. The

Hechinger

report,
6

November. 
https://hechingerreport.org/federal-data-shows-3-9-million-students-dropped-college-debt-2015-2016/

Benn, Roseanne. (1995). Higher education: Non-standard students and withdrawals, Journal of Further and Higher Education, 19(3), 3-12. https://doi.org/10.1080/0309877950190301

Ehrenberg, Andrew (1988). Repeat-buying ( $2^{\text {nd }}$ ed.). Charles Griffing \& Company, London, 2, 79.

Bogdanov D., Kamm L., Laur S., Pruulmann-Vengerfeldt P., Talviste R. \& Willemson J. (2014). Privacy-preserving statistical data analysis on federated databases. In Preneel, B \& Ikonomou D. (eds) APF, LNCS, 8450, Springer, Heidelberg, 30-55. https://doi.org/10.1007/978-3-319-06749-0_3

Bradburn, E. (2002). Short-term enrollment in postsecondary education: Student background and institutional differences in reasons for early departure, 1996-1998. Education Statistics Quarterly, 4. http://nces.ed.gov/pubs2003/quarterly/winter/q4_2.asp https://doi.org/10.1037/e610562011-008

Braxton \& McClendon (2002). The fostering of student integration and retention through institutional practice. Journal of College Student Retention: Research, Theory \& Practice, 3(1), 57-71.https://doi.org/10.2190/RGXJ-U08C-06VB-JK7D

Cambiano, R., Denny, G. \& DeVore, J. (2000). College student retention at a midwestern university: A six years study. Journal of College Admissions, 166, 22-29.

Cervini, Erica (2015). Dropout, drop in: It's time universities re-recruited their discontinued students. The Sydney Morning Herald, $20^{\text {th }} \quad$ August. http://www.smh.com.au/national/education/drop-out-drop-in-its-time-universities-rerecruited-their-discontinu ed-students-20150819-gj2qgu.html

Chen, Rong \& DesJardins, Stephen L. (2010). Investigating the Impact of Financial Aid on Student Dropout Risks: Racial and Ethnic Differences. The Journal of Higher Education, 81(2), 179-208.https://doi.org/10.1080/00221546.2010.11779048

Cambridge dictionary (2017). Cambridge University Press. https://dictionary.cambridge.org/dictionary/english/dropout

Dianda, Marcella R. (2008). Preventing Future High School Dropouts an Advocacy and Action Guide for NEA State and Local Affiliates. National Education Association, Washington, USA, 6(9), 51. http://www.nea.org/assets/docs/HE/dropoutguide1108.pdf

Doll J.J., Eslami Z. \& Walters L. (2013). Understanding Why Students Dropout of High School, According to Their Own Reports: Are They Pushed or Pulled, or Do They Fall Out? A Comparative Analysis of Seven Nationally Representative Studies. Sage Open, https://www.voced.edu.au/content/ngv\%3A59369https://doi.org/10.1177/2158244013503834

Drucker F., Peter. (1967). The effective decision. Harvard Business Review, January. https://hbr.org/1967/01/the-effective-decision

Duke, Chris (2005). The role of higher education institutions in regional development, Report on an international seminar held at Karlstad University, Sweden, 4 \& 5 Oct, 2005. http://www.oecd.org/sweden/35887469.pdf

Edmondson, A. \& Cannon, M.D. (2005). The Hard Work of Failure Analysis, HBS publishing, 22, Aug.

El Shammaa, Dina (2010). 25\% of Emiratis dropout of school after second year. Gulf News Education, $6^{\text {th }}$ October. https://gulfnews.com/news/uae/education/25-of-emiratis-drop-out-of-school-after-second-year-1.692335

Going Global, British Council Analysis (2012). The shape of things to come: higher education global trends and emerging $\quad$ opportunities to 2020 . https://www.britishcouncil.org/sites/default/files/the_shape_of_things_to_come_-_higher_education_global_t rends_and_emerging_opportunities_to_2020.pdf

Harton, Joann. (2015). Identifying At-Risk Factors That Affect College Student Success. International Journal of Process Education, 7(1), 83-101. https://www.ijpe.online/2015/risk.pdf

Herzog, Serge. (2005). Measuring determinants of student return vs. Dropout/stopout vs. Transfer: A First-to-Second Year Analysis of New Freshmen. Research in Higher Education, 46(8), 883-928. https://doi.org/10.1007/s11162-005-6933-7

Hoff N., Olson. A. \& Peterson, R.L. (2015). i, University of Nebraksa-Lincoln, USA. https://k12engagement.unl.edu/DropoutScreening\&EarlyWarning3-27-15.pdf 
Johnson, J. (1997). Commuter college students: What factors determine who will persist and who will dropout? College Student Journal, 31, 323-332. http://connection.ebscohost.com/c/articles/9710031688/commuter-college-students-what-factors-determine-w ho-will-persist-who-will-drop-out

Kay, Michael F. (2015). The Law of Unintended Consequences -- And Your Money, October 13, Forbes.com.www.forbes.com/sites/michaelkay/2015/10/13/the-law-of-unintended-consequences-and-your-mo ney/\#17a19e002f49

Kern, C., Fagley, N. \& Miller, P. (1998). Correlates of college retention and GPA: Learning and study strategies, testwiseness, attitudes, and ACT. Journal of College Counseling, 1, 26-34. https://doi.org/10.1002/j.2161-1882.1998.tb00121.x

Kift, Sally. (2014). Student success: why first year at uni is a make-or-break experience. The Conversation, $19^{\text {th }}$ February.

http://theconversation.com/student-success-why-first-year-at-uni-is-a-make-or-break-experience-21465

Lee, V.E. \& Burkam, D.T. (2003). Dropping out of high school: The role of school organization and structure. American Educational Research Journal, 40(2), 353-393. https://doi.org/10.3102/00028312040002353

Lillis, Michael. P. (2011). Faculty Emotional Intelligence and Student-Faculty Interactions: Implications for Student Retention. Journal of College Student Retention: Research, Theory \& Practice, 13(2), August. https://doi.org/10.2190/CS.13.2.b

MacDonald, I. (1992). Meeting the needs of non-traditional students: Challenge or opportunity for higher education. Scottish Journal of Adult Education, 1(2), 34-44.

Mainardes, E.W., Alves, H. \& Raposo, M. (2010). An Exploratory Research on the Stakeholders of a University. Journal of Management and Strategy, 1(1), 76-88. https://doi.org/10.5430/jms.v1n1p76

MCBS Policy Manual (2016). Information security policy. Policy Area: IT Policy, MCBS SharePoint Portal, 140-146.

McGaha, Valerie. \& Fitzpatrick, Jacki. (2005). Personal and social contributors to dropout risk for undergraduate students. $\quad$ College Student http://www.freepatentsonline.com/article/College-Student-Journal/133606099.html

Muscat, Daily. (28 Dec, 2016). High dropout rate from colleges cause of concern: SQU Counsellor. http://www.muscatdaily.com/Archive/Oman/High-dropout-rate-from-colleges-cause-of-concern-SQU-Counse llor-4wmc

O'Donovan, Peter. (2017). Analysing Ireland's high third level dropout rates. Trinity News, $6^{\text {th }}$ February. http://trinitynews.ie/analysing-irelands-high-third-level-dropout-rates/

Organisation for Economic Co-operation and Development (2007). Higher Education Facilities: Issues and Trends, PEB Exchange, OECD. https://www.oecd.org/edu/innovation-education/38168377.pdf

Oswald, D. \& Clark, E. (2003). Best friends forever?: High school best friendships and the transition to college. Personal Relationships, 10, 187-196. https://doi.org/10.1111/1475-6811.00045

Pourmohammadi, Elham. (2016). Call to stem high student dropout rate in Oman. Opinion, Times of Oman, $8^{\text {th }}$ January.

http://timesofoman.com/article/75093/Oman/Education/Joint-efforts-needed-to-address-student-dropout-probl em-in-Oman-says-Minister-of-Higher-Education

Rassekh, Shapour. (2004). Education as a motor for development: Recent education reforms in Oman with particular reference to the status of women and girls, International Bureau of Education, Geneva, Switzerland.http://www.ibe.unesco.org/fileadmin/user_upload/archive/Publications/innodata/inno15.pdf

Rausch, J.D. \& Rausch, M. (2015). But I Learned All This in High School: Modeling Why Students Drop Core Curriculum Courses.

ResearchGate. https://www.researchgate.net/publication/268198697_But_I_Learned_All_This_in_High_School_Modeling_ Why_Students_Drop_Core_Curriculum_Courses

Reyhner, Jon. (1992). Plans for Dropout Prevention and Special School Support Services for American Indian and Alaska Native Students. Journal of American Indian Education, January. 
https://files.eric.ed.gov/fulltext/ED343762.pdf

Ridge, N., Farah, S. \& Sami, S. (2013). Patterns and Perceptions in Male Secondary School Dropouts in the United Arab Emirates. Working paper, $\quad$ 03, http://www.alqasimifoundation.com/admin/Content/File-1612201535124.pdf

Rooney, J. J. \& Heuvel, Lee N. V. (2004). Root cause analysis for beginners, Quality Progress, July, $45-53$. http://asq.org/quality-progress/2004/07/quality-tools/root-cause-analysis-for-beginners.html

Saunders, Mark, Lewis, Philip \& Thornhill, Adrian (2007). Research Methods for Business Students, 4 e, Prentice Hall, UK, 246-263.

Selingo, Jeffrey J. (2016). Two-Thirds of College Grads Struggle to Launch Their Careers. Harvard Business Review, May 31. https://hbr.org/2016/05/two-thirds-of-college-grads-struggle-to-launch-their-careers

Shaibany, Saleh (2016). Higher education student dropout rate in Oman is a cause for concern. Opinion, Times of Oman, $23^{\text {rd }}$ January. http://timesofoman.com/article/75995

Smith J.P. \& Naylor R.A. (2001). Dropping out of university: a statistical analysis of the probability of withdrawal for UK university students. Journal of Royal Statistical Society, 164(2), 389-405. https://doi.org/10.1111/1467-985X.00209

Swail, Watson. Scott. (2004). The art of student retention-A handbook for practitioners and administrators, 20th Annual Recruitment and Retention Conference, Texas Higher Education Coordinating Board, $21^{\text {st }}$ June, Texas, USA. https://eric.ed.gov/?id=ED485498

The Economist (2013). Data is the lifeline of business decisions. Report from the Economist Intelligence Unit. https://www.emc.com/collateral/white-papers/ei-evolving-role-data-decision-making.pdf

Tickle, Louise (2015). How universities are using data to stop students dropping out. The Guarding, International edition, $30^{\text {th }} \quad$ June. https://www.theguardian.com/guardian-professional/2015/jun/30/how-universities-are-using-data-to-stop-stud ents-dropping-out

Times of Oman (26 Sep, 2016). Oman education: More than 10,000 students dropped out of colleges. http://timesofoman.com/article/93017

UNESCO (1991). The Role of Higher Education in Society Quality and Pertinence. UNESCO, Non-Governmental Organizations 2nd Collective Consultation on Higher Education, Paris, 8-11 April. http://www.unesco.org/education/pdf/24_133.pdf

Vazquez-Abad, J., Winer, L. \& Derome, J. (1997). Why some stay: A study of factors contributing to persistence in undergraduate physics (FN1). McGill Journal of Education, 32, $209-229$. https://pdfs.semanticscholar.org/f073/94e607443e7df11a6abfd6f1c3ead2a97f22.pdf

Woodley, A., Thompson, M. \& Cowan, J. (1992). Factors affecting non-completion rates in Scottish Universities, SRC Report, 69. 


\section{Appendices}

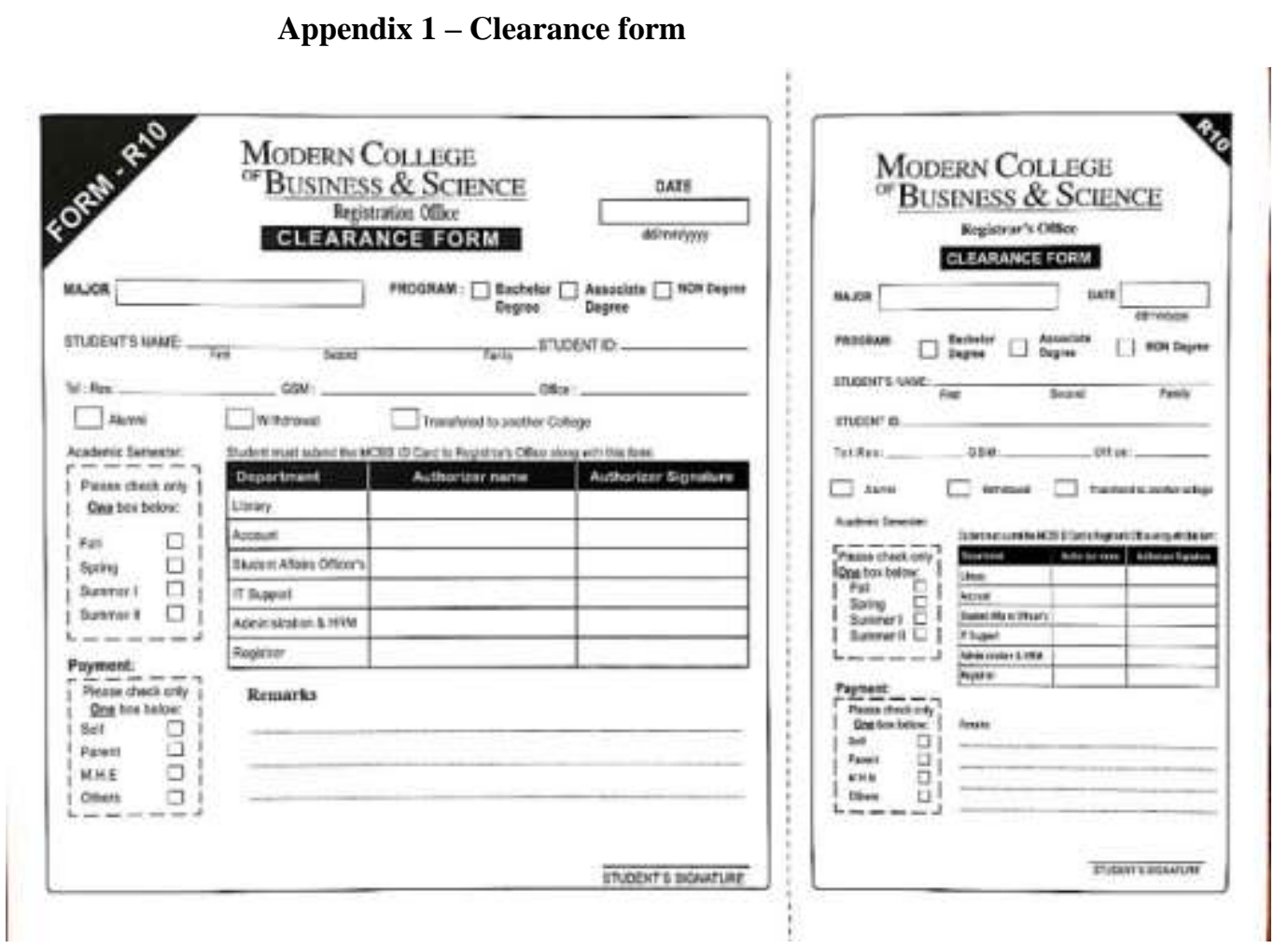

Appendix 2 - Semester-wise registration and dropout data

\begin{tabular}{lrrcc}
\hline \multicolumn{1}{c}{ Term } & No. dropped & Percentage & No. registered & \% \\
\hline Spring 2012 & 99 & $5 \%$ & 745 & $13 \%$ \\
Summer I 2012 & 2 & $0.1 \%$ & 137 & $1 \%$ \\
Summer II 2012 & 75 & $3.8 \%$ & 702 & $11 \%$ \\
Fall 2012 & 215 & $10.9 \%$ & 1102 & $20 \%$ \\
Spring 2013 & 178 & $9.1 \%$ & 1064 & $17 \%$ \\
Summer I 2013 & 0 & $0 \%$ & 248 & -- \\
Summer II 2013 & 2 & $0.1 \%$ & 760 & -- \\
Fall 2013 & 242 & $12.3 \%$ & 1114 & $22 \%$ \\
Spring 2014 & 318 & $16.2 \%$ & 1299 & $24 \%$ \\
Summer I 2014 & 0 & $0 \%$ & 172 & -- \\
Summer II 2014 & 138 & $7 \%$ & 757 & $18 \%$ \\
Fall 2014 & 159 & $8.1 \%$ & 1103 & $14 \%$ \\
Spring 2015 & 129 & $6.6 \%$ & 924 & $14 \%$ \\
Summer I 2015 & 3 & $0.2 \%$ & 245 & -- \\
Summer II 2015 & 43 & $2.2 \%$ & 598 & $7 \%$ \\
Fall 2015 & 138 & $7 \%$ & 1012 & $14 \%$ \\
Spring 2016 & 92 & $4.7 \%$ & 870 & $11 \%$ \\
Summer I 2016 & 2 & $0.1 \%$ & 182 & -- \\
Summer II 2016 & 38 & $1.9 \%$ & 591 & $6 \%$ \\
Fall 2016 & 89 & $4.5 \%$ & 842 & $11 \%$ \\
Spring 2017 & 2 & $0.1 \%$ & 735 & -- \\
Summer I 2017 & 2 & $0.1 \%$ & 395 & -- \\
Grand Total & $\mathbf{1 9 6 6}$ & & $\mathbf{1 5 5 9 7}$ & \\
\hline
\end{tabular}


Appendix 3 - Level-wise dropout

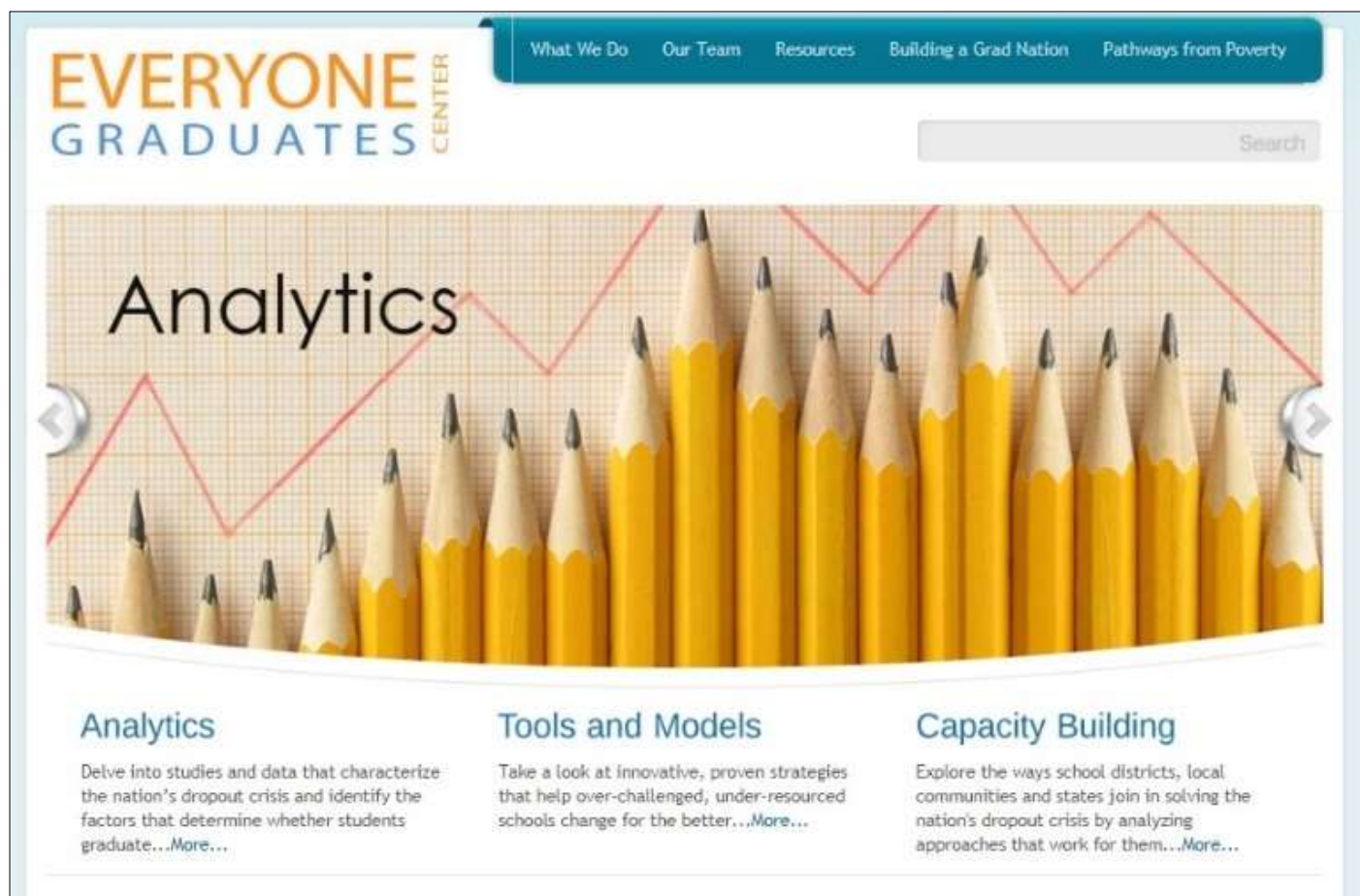

Appendix 4 - Everyone Graduates Center, John Hopkins University, USA

\begin{tabular}{ccc}
\hline Level & Number & \% \\
\hline Level 1 & 806 & $41 \%$ \\
Level 2 & 334 & $17 \%$ \\
Level 3 & 256 & $13 \%$ \\
Level 4 & 570 & $29 \%$ \\
Grand Total & $\mathbf{1 9 6 6}$ & $\mathbf{1 0 0 \%}$ \\
\hline
\end{tabular}

Appendix 5

\begin{tabular}{|c|c|c|c|c|}
\hline \multicolumn{5}{|c|}{ Courses offered in Foundation Program } \\
\hline Level 1 & Level 2 & Level 3 & Level 4 & $\begin{array}{c}\text { Areas } \\
\text { covered }\end{array}$ \\
\hline ENGL 0011 & ENGL 0021 & ENGL 0031 & ENGL 0041 Listening \& & Speaking, \\
\hline $\begin{array}{l}\text { Listening \& } \\
\text { Speaking }\end{array}$ & $\begin{array}{l}\text { Listening \& } \\
\text { Speaking }\end{array}$ & $\begin{array}{l}\text { Listening \& } \\
\text { Speaking }\end{array}$ & Speaking & $\begin{array}{l}\text { listening \& } \\
\text { note taking }\end{array}$ \\
\hline ENGL 0012 & ENGL 0022 & ENGL 0032 & ENGL 0042 Reading \& & \\
\hline $\begin{array}{l}\text { Reading \& } \\
\text { Writing }\end{array}$ & $\begin{array}{l}\text { Reading \& } \\
\text { Writing }\end{array}$ & $\begin{array}{l}\text { Reading \& } \\
\text { Writing }\end{array}$ & Writing & Reading \\
\hline $\begin{array}{c}\text { ENGL } 0013 \\
\text { Grammar }\end{array}$ & $\begin{array}{c}\text { ENGL } 0023 \\
\text { Grammar }\end{array}$ & $\begin{array}{c}\text { ENGL } 0033 \\
\text { Grammar }\end{array}$ & ENGL 0043 Grammar & $\begin{array}{c}\text { Grammar \& } \\
\text { writing }\end{array}$ \\
\hline ORNT 001 & & MATH 10 & MATH 20-Applied & \\
\hline Orientation-I & ource: MCBS & $\begin{array}{c}\text { Basic } \\
\text { Mathematics }\end{array}$ & $\begin{array}{c}\text { Mathematics or } \\
\text { MATH 21-Pure } \\
\text { Mathematics } \\
\text { COSC } 10 \text { Fundamentals } \\
\text { of Computing } \\
\text { 17-2018, pp.11 }\end{array}$ & $\begin{array}{l}\text { Math \& } \\
\text { Computer } \\
\text { skills }\end{array}$ \\
\hline
\end{tabular}

